\title{
臨床経験
}

\section{当院における腹腔鏡補助下幽門側胃切除術の導入一倫理的問題に 対する配慮および導入初期成績と後期成績との比較一}

\author{
愛知県がんセンター愛知病院消化器外科, 名古屋大学画像情報外科* \\ 小島泰樹松井隆則小島宏 \\ 藤 原 道 隆*
}

\section{Learning Experience of Laparoscopy Assisted Distal Gastrectomy in Our Hospital}

\author{
Taiki KOJIMA, Takanori MATSUI, Hiroshi KOJIMA \\ and Michitaka FUJIWARA* \\ Department of Gastroenterological Surgery, Aichi Cancer Center Aichi Hospital \\ *Department of Surgery II, Nagoya University School of Medicine
}

\begin{abstract}
腹腔鏡補助下胃切除術は保険診療として認められているものの, 胃癌治療がイドラインでは, 標準治療ではな く臨床研究と位置づけられている。また，新しい手術手技を導入するのにラーニングカーブは不可避であるが, この時期の患者の不利益を極力減らすべきなのは言うまでもない。当院では腹腔鏡補助下胃切除術の導入にあた ク，これらの倫理的問題に対する配虑として，導入方法に関して，院内の倫理審査委員会での承認をうけた。そ の主な内容とは，(1) 初期症例10例に扔いては院外からの内視鏡外科技術認定医の指導をうけること，(2)当院に おいてはまだ導入期の手術であることと，この方法がガイドラインでは標準治療でなく臨床研究という位置づけ であることを患者本人に説明し，患者本人からそれらを記載した文書による同意書の取得を行うこと，の 2 点で あった。導入はスムーズに行われ，初期症例10例とそれに続く 15 症例との間で，出血量や手術時間に有意な差は みられず，合併症の増加もみられなかった。
\end{abstract}

索引用語：腹腔鏡補助下幽門側胃切除術 (laparoscopy assisted distal gastrectomy), 導入 (learning curve)

\section{はじめに}

腹腔鏡補助下胃切除術 (Laparoscopy Assisted Distal Gastrectomy，以下LADG）は保険診療と して認められているものの, 胃癌治療ガイドライ ン1では, 標準治療ではなく臨床研究と位置づけ られている。また，新しい手術手技を導入するの にラーニングカーブは不可避であるが，この時期 の患者の不利益を極力減らすべきなのは言うまで もない。当院（愛知県がんセンター愛知病院消化 器外科）では2006年 3 月より LADGを本格的に導 入したが，導入にあたって行った，これらの倫理
的問題に対する配慮について紹介する。また，院 外からの直接指導のあった前期症例と, その後の 後期症例との比較についても報告する。

\section{対象および方法}

既に当院において，LADGは1999年 1 月から 2005年 2 月まで，10例施行している。だが， 2006 年, 新しい光学機器の導入を契機として, 本手技 についての倫理的配慮について再検討を行うこと にした。

まず，当院でLADGを行うことについてあらた めて院内の倫理審査委員会に申請, 承認をうけた。 


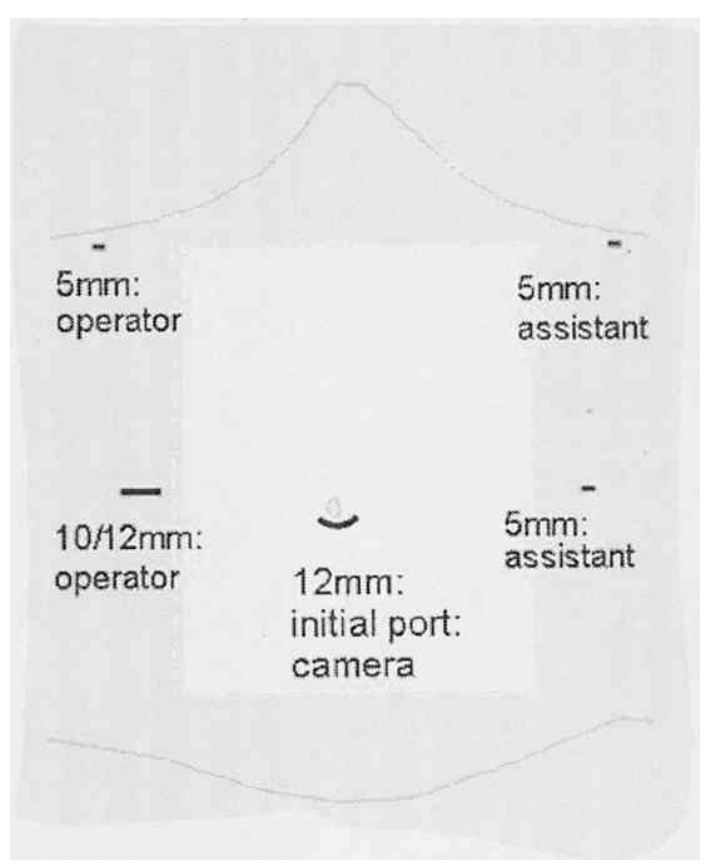

Fig. 1 Example of our manual (the site of port insertion)

その主な内容は，(1) 最初の10例については，院外 (名古屋大学画像情報外科) からの内視鏡外科技 術認定医の指導をうけること, (2) 患者本人に対し て, 本治療は胃癌治療ガイドラインでは標準治療 でなく臨床研究という位置づけにあることと, 当 院において本治療はまだ導入期で院外からの指導 をうけながら手術を行うことを説明し，患者本人 からの文書による同意書の取得を行うこと，の 2 点であった。

また，初期症例 10 例の院外からの直接指導と同 時に, 名古屋大学関連病院共通の教育システムを 導入した ${ }^{2)}$ 。術者は, 事前にきめられたシミュレー 夕による基本手技訓練を行い, 医師用および看護 師用のマニュアルを入手, 学習した。マニュアル からの抜粋例を Fig. 1，2に提示した。直接指導の 際には, ポート扦入位置や扱入方法, 視野確保の 手順, 術者, 助手, カメラ医の役割分担, リンパ 節郭清手技，吻合法等，すでに確立されたものを 踏襲することができた。

このようにして，2006年 3 月より2007年12月ま での間に，内視鏡治療の適応でない術前診断にて T1N0胃癌に対して，25症例のLADGを施行した。

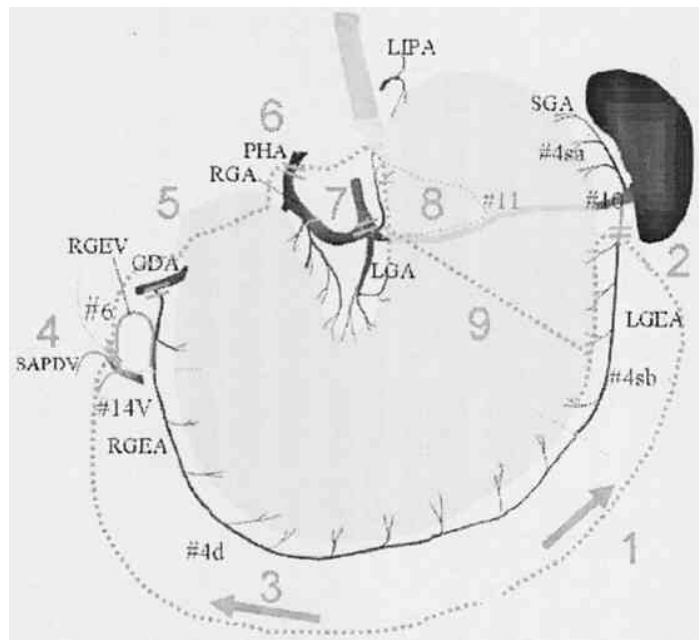

Fig. 2 Example of our manual (operation procedure)

Dissection of

1. left-side greater omentum

2. left gastroepiploic artery

(No.4sb lymph nodes resection)

3. right-side greater omentum

(No.4d lymph nodes)

4. right gastroepiploic vein

(No.14V, 6 lymph nodes)

right gastroepiploic artery and infrapyloric artery

5. duodenum

6. right gastric artery

(No.5,12 lymph nodes)

7. lymph nodes around common hepatic artery(No.8 lymph nodes), around left gastric artery(No.7 lymph nodes), around celiac artery(No.9 lymph nodes)

8. Iymph nodes around splenic artery

(No.11p lymph nodes) and of upper lesser curvature (No.1 lymph nodes)

9. stomach

\section{成 績}

25症例の患者背景についてはTable 1 のとおり である。男性18例, 女性 7 例, 年齢は $34 \sim 75$ 歳で ある。術前診断はすべて T1N0の早期胃癌で，うち 3 例はESD後のリンパ節郭清目的であった。

手術のリンパ節郭清度は, 初期症例の 1 例が 
腹腔鏡補助下幽門側胃切除術の導入

Table 1 Characteristics of patients

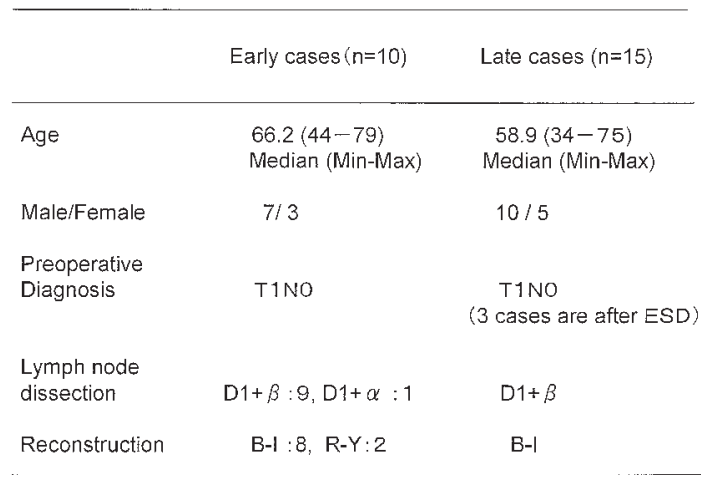

$\mathrm{D} 1+\alpha$ だった以外はD $1+\beta$, 再建方法は, 初期症例 に 2 例 $\mathrm{R}-\mathrm{Y}$ を行った他はB-I法であった。25例の うち, 開腹手術移行例は, 後期症例での 1 例で, 理由は胃切除後胃切開にて進行癌と判断LD2郭 清の徹底目的だった。

合併症としては, 初期症例に 1 例創感染を認め たが, 縫合不全, 吻合部狭窄, 心肺合併症等の合 併症は全例を通じて経験していない。術後の病理 では前期症例でN1が 2 例, 後期症例でN 2 が 1 例 であった以外は $\mathrm{N} 0$ 。後期症例で 1 例, 術後病理に て口側断端が陽性にて再手術で残胃全摘を行った 症例があった (signet ring cell, 再手術後の病理 では残胃に遺残なし)。

院外からの直接指導のあった初期症例とその後 の後期症例の成績比較をTable 2 に示した。初期 症例と後期症例での出血量および手術時間に, 有 意な差はみられなかった。また手術侵襲の指標と しての術後第 1 病日のCRP, 術中ペンロースドレ ーンによる肝挙上に伴う術後第 1 病日のGOT, GPTの上昇 ${ }^{3}$ についても初期症例と後期症例との 間に有意な差はみられなかった。

なお，全体の症例を通じて，BMIと手術時間 $(\mathrm{r}=0.44, \mathrm{p}=0.03)$ あるいは出血量 $(\mathrm{r}=0.50$, $\mathrm{p}=0.01)$ との正の弱い相関関係が認められた

(Fig. 3A, B)。BMIはまた, 術後第一病日の CRP ( $\mathrm{r}=0.47, \mathrm{p}=0.02)$ と弱い相関を示した

(Fig. 3C) が, 同日のGOT $(\mathrm{r}=0.18, \mathrm{p}=0.39)$, $\operatorname{GPT}(r=0.27, p=0.19)$ の值とは相関しなかっ た。
Table 2 Comparison between early cases and late cases

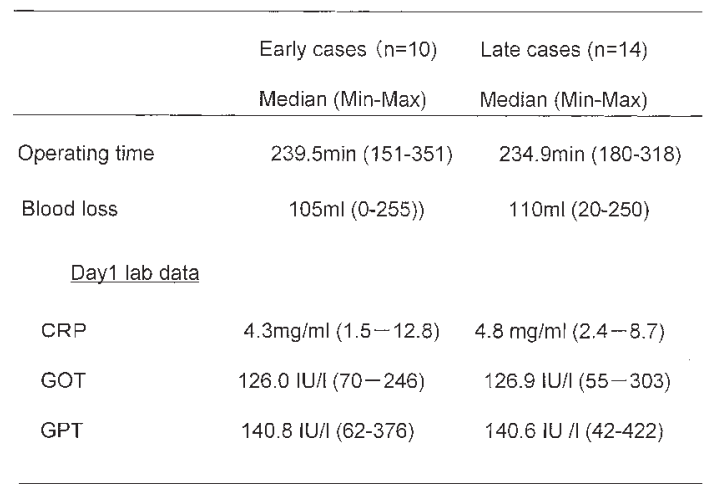

\section{考察}

既に当院において，LADGは1999年 1 月から 2005年 2 月まで，10例施行されていたが，今回あ らためて倫理審査委員会の承認を得ることとした のは, 近年, ガイドラインに沿った標準治療を行 うことについてのわれわれの意識が高まったこと が大きい。

一方，今回（2006年以降）の導入以後，それま で日常診療として根づかなかったLADGが日常診 療として行えるようになってきた。これは, 今回， 新しい光学機器の導入により視野が格段によくな ったことが大きいと思われるが，それに加え，倫 理的な手続きを経て行っているという安心感や, 定型化が進んできたLADG野の手技 ${ }^{223)}$ を学習し， 直接指導をうける機会をえたことも影響している と思われる。

出血量や手術時間は，LADG手技習得の目安と なると言われているが4), 今回においては初期症 例から後期症例にスムーズな移行が行われ, 患者 にとっても，導入時期の不利な条件を最小におさ えることができたと考える。

ただし，個々の症例をみると，時に手術時間が 突出する症例がみられた $($ Fig. 4)。これらはBMI の高い症例に多いということが, BMIと手術時間 の相関関係がみられたころから予想される (Fig. $3)$ 。LADGの手術時間や出血時間が肥満と関係し ているということについては既にいくつかの報告 がみられる ${ }^{5)}$ 。脂肪が多いと, 脂肪組織内に血管が 
A. Operating time (min)

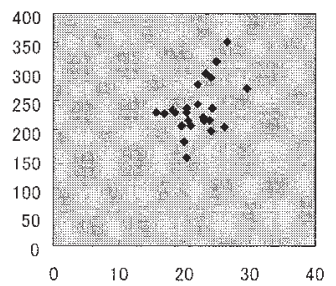

BMI
B. Blood loss $(\mathrm{ml})$

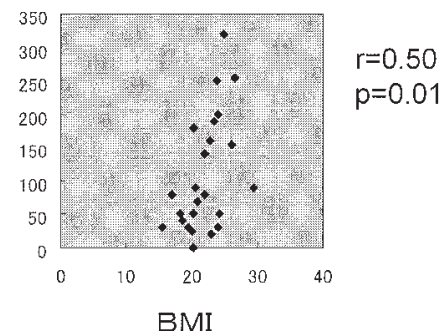

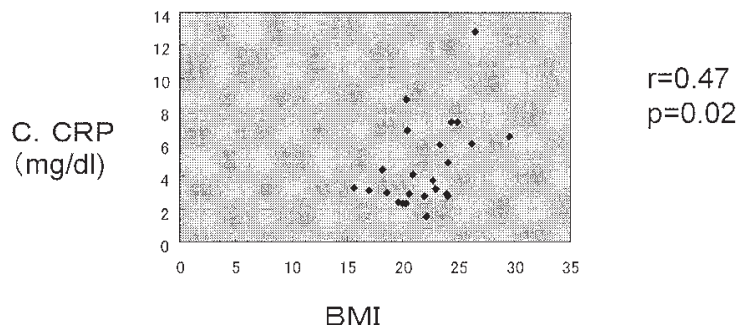

Fig. 3 Correlation between BMI and Operating time, Blood loss, CRP

(A) Operating time $(r=0.44, p=0.03)$

(B) Blood loss $(r=0.50, p=0.01)$

(C) CRP $(r=0.47, p=0.02)$

\section{Operating time $(\mathrm{min})$}

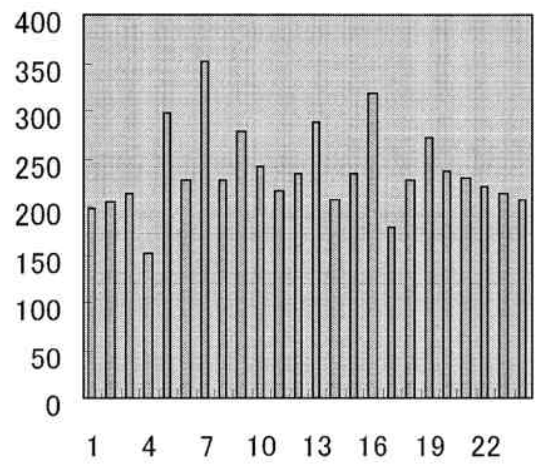

\section{Consecutive cases}

Fig. 4 Operating time of all 24 cases

埋もれて同定や剝離がしにくかったり，膵臓と脂 肪の境界がわかりにくくなるといったことは手技 上実感するところである。一方，肝挙上の手技で はこのような脂肪の影響は少なく，われわれの症 例の解析でも肝挙上に伴うGOT, GPTの值の上 昇はBMIと相関しなかった。

いずれにせよ，手術時間のばらつきをすべて
BMIでは説明できないと思われる。また，われわ れの症例において, 肥満症例で手術時間や出血量 が多いとはいえ，全症例を通じて大きな合併症は 経験してはおらず，肥満症例が禁忌とまでは言え ないと思われる。肥満症例に対する適応について は今後症例を重ねながら検討していく予定であ る。

LADGは大学病院を中心に既にさかんに行われ ているが，国公立がんセンターや一般病院で導入 している施設は多いとは言えない6)。これは, 胃癌 治療がイドラインで，LADGは日常診療で行われ るべき標準治療として推奨されていないことが大 きい理由のひとつと思われる。だが一方，同じガ イドラインには「十分な経験を持った外科医によ るLADGは身体により優しい治療法として将来普 及するようになる方法」とも記されている。

当院で行ったような, 院内の倫理審查委員会を 通し，大学病院からの技術支援をうけるというス テップをふむことは，一般病院で，ガイドライン 上臨床研究とされる本手技を日常診療に取り入れ る際に重要なことと考える。 


\section{おわりに}

既に過去に当院で経験のあったLADGの手技 も, 倫理的手続きや学習面での見直しをはかるこ とで, 日常診療として定着させることが可能とな つた。また, 肥満症例に対する適応について, 今 後の検討を要することが示唆された。

\section{参考文献}

1）日本胃癌学会編：胃癌治療ガイドライン医師用 2004年 4 月改定. 第 2 版，金原出版，東京，2004

2) Fujiwara M, Kodera Y, Nakao A, et al : Laparoscopy-assisted distal gastrectomy with systemic lymph node dissection : a phase II study following the learning curve. J Surg Oncol 91 : 26-32, 2005
3）藤原道隆，三澤一成，中尾昭公他：胃癌に対する 鏡視下手術の現状と展望. 外科治療 $95 ： 405-406$, 2006

4) Kim MC, Jung GJ, Kim HH : Learning curve of laparoscopy-assisted distal gastrectomy with systemic lymphadenectomy for early gastric cancer. World J Gastroenterol 11 : 7508-7511, 2005

5) Kim KH, Kim MC, Jung GJ, et al : The impact of obesity on LADG for early gastric cancer. Gastric Cancer 9 : 303-307, 2006

6）鈴木恵史，富永幸治，村田 順他：民間グループ 病院における腹腔鏡補助下胃切除術の検討一導 入初期成績と技術支援について一. 日外科系連会 誌32：632-637，2007 